\title{
Synthesis, characterization and biological activity of a gold(I) triazenide complex against chronic myeloid leukemia cells and biofilm producing microorganisms
}

\author{
Melise Silveira Nunes ${ }^{1}$, Litiérri Razia Garzon', Roberta Filipini Rampelotto', Maísa Kräulich \\ Tizotti $^{1}$, Rosiéli Martini' ${ }^{1}$, Aline Locatelli², Marcelo Barbosa ${ }^{3}$, Manfredo Hörner ${ }^{1}$, Rosmari Hörner ${ }^{{ }^{*}}$ \\ ${ }^{1}$ Federal University of Santa Maria (UFSM), Santa Maria, Rio Grande do Sul, Brazil, ${ }^{2}$ University of Passo Fundo, Passo \\ Fundo, Rio Grande do Sul, Brazil, ${ }^{3}$ Universitary Hospital of Santa Maria (HUSM), Santa Maria, Rio Grande do Sul, Brazil
}

\begin{abstract}
The enhancement of anti-leukemia therapy and the treatment of infections caused by multidrug-resistant pathogens are major challenges in healthcare. Although a large arsenal of drugs is available, many of these become ineffective, and as a result, the discovery of new active substances occurs. Notably, triazenes (TZCs) have been consolidated as a promising class of compounds, characterized by significant biological activity, especially antiproliferative and antimicrobial properties. The aim of this study is the synthesis and characterization of a new triazenide complex of gold (I), as well as the in vitro assessment of its antiproliferative activity against the K562 cell line (Chronic Myeloid Leukemia), and antibacterial activity against bacterial isolates of biofilm-producing coagulase-negative staphylococci. The combination of TZC with gold metal tends to have a synergistic effect against all biofilm-producing isolates, with Minimum Inhibitory Concentration values (MIC) between 32 and $64 \mu \mathrm{g} \mathrm{mL}^{-1}$. It has also shown activity against $\mathrm{K} 562$ cell line, getting an $\mathrm{IC}_{50}=4.96 \mu \mathrm{M}$. Imatinib mesylate (Glivec) was used as reference, with $\mathrm{IC}_{50}=3.86 \mu \mathrm{M}$. To the best of our knowledge, this study represents the first report of the activity of a TZC complexed with gold ion in the oxidation state (I) against microorganisms that produce biofilm and K562 cells.
\end{abstract}

Keywords: Triazenes/synthesis/characterization/biological activity. TZC/Gold ion complexed. .Chronic myeloid leukemia. Antibacterial activity.

\section{INTRODUCTION}

Chronic myeloid leukemia (CML) is an hematologic malignancy characterized by excessive myeloid proliferation and the presence of a cytogenetic abnormality known as the Philadelphia chromosome $(\mathrm{Ph})$, which occurs in $90 \%$ of CMLs, $20 \%$ of acute lymphocytic leukemia (ALLs) in adults, $5 \%$ of pediatric ALLs, and $1 \%$ of acute myeloid leukemia (AML) patients (Heim, Mitelman, 2009). This change stems from the reciprocal and balanced translocation between the long arms of chromosomes 9 and 22, $\mathrm{t}(9 ; 22)$ (q34; q11.2), resulting in BCR-ABL abnormal gene (Gora-Tybor, Robak, 2008;

\footnotetext{
*Correspondence: R. Hörner. Laboratório de Bacteriologia, Departamento de Análises Clínicas e Toxicológicas, Centro de Ciências da Saúde, Universidade Federal deSanta Maria (UFSM), Santa Maria,RS. Prédio 26, Sala1201, Campus da UFSM, CEP: 97015-900. Telefax: +55(55) 3220-8751. E-mail: rosmari.ufsm@gmail.com
}

Chauffaille, Bandeira, Silva, 2014). This oncogene encodes the production of a chimeric protein with high tyrosine kinase activity, which is directly related to the pathogenesis of CML (Gora-Tybor, Robak, 2008).

A major breakthrough in the treatment of CML has been achieved with the advent of selective inhibitors of tyrosine kinase such as imatinib mesylate (Glivec) and its derivatives. Despite the good results obtained by these drugs, the lack of response to treatment that occurs when cancer cells develop resistance mechanisms is an important outcome of this disease (Yun et al., 2014; Wang et al., 2015).

Similarly, antimicrobial therapy constitutes a challenge due to the ease with which bacteria acquire resistance genes transmitted by mobile genetic elements (Brown-Jaque, Calero-Cáceres, Muniesa, 2015). Biofilm formation is one of the major virulence factors developed by bacteria. Biofilm is commonly associated with chronic 
infections because it resists host defense systems and has increased tolerance to antibiotics and disinfectants (Høiby et al., 2010).

Triazene compounds (TZCs) are characterized by the diazoamine group $(\mathrm{N}=\mathrm{N}-\mathrm{N})$ (Moore, Robinson, 1986), which accounts for their biological properties (Marchesi et al., 2007). They have a broad pharmacological versatility: antibacterial (Horner et al., 2008; Domingues et al., 2010; Ombaka, Muguna, Gichumbi, 2012; Tizotti et al., 2016), antifungal (Ombaka, Muguna, Gichumbi, 2012), antileukemic (Matheson et al., 2004; Domingues et al., 2010; Bonmassar et al., 2013; Tizotti et al., 2016), and synthetic nuclease (Domingues et al., 2010). Dacarbazina ${ }^{\circledR}$ and Temozolomida ${ }^{\circledR}$ are examples of TZC compounds widely used in the clinical treatment of various malignancies (Bonmassar et al., 2013).

The combination of the pharmacophoric radical TZC with metal ions that have biological activity such as ion gold tends to have a synergistic effect, producing more active and stable molecules (Sreedhara, Cowan, 2001). Thus, this study aimed to synthesize and characterize a new triazenide compound complexed with ion gold (I), as well as to evaluate the in vitro antiproliferative and antibacterial activity against the cell line K562 (CML) and bacterial isolates of coagulase-negative staphylococci (CoNS), identified as biofilm producers.

\section{MATERIAL AND METHODS}

\section{Synthesis of $\mathrm{Au}(\mathrm{I})$ triazenide complex \{[(1-(2-bromophenyl)-3-(2-nitrophenyl) triazenide](triphenylphosphine)gold(I)\}}

Under continuous stirring, the free ligand 1-(2-bromophenyl)-3-(2-nitrophenyl)triazene $\mathrm{C}_{12} \mathrm{H}_{9} \mathrm{~N}_{4} \mathrm{O}_{2} \mathrm{Br}$ $(100 \mathrm{mg}, 0.311 \mathrm{mmol})$ was dissolved in a mixture of $20 \mathrm{~mL}$

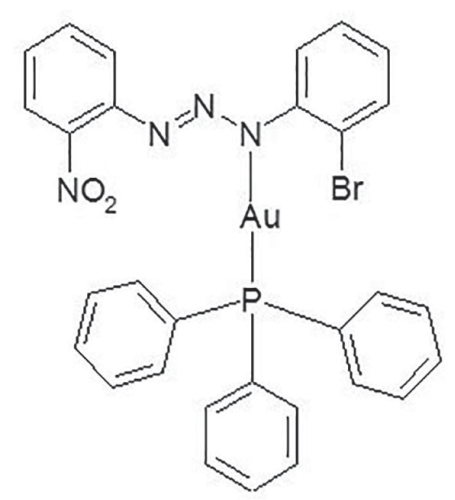

FIGURE 1 - Structure of the triazenide gold (I) complex : \{[1-(2-bromophenyl) -3- (2-nitrophenyl) triazenide] (triphenylphosphine) gold (I) $\}$. of methanol and tetrahydrofuran (1:1), resulting in a yellow transparent solution. The free ligand was deprotonated by the addition of 5 drops of an alkaline solution of potassium methoxide, previously prepared by dissolution of potassium hydroxide (1000 mg, $17.82 \mathrm{mmol})$ in $10 \mathrm{~mL}$ of methanol. The reaction mixture changed to transparent deep-red. After stirring of the reaction mixture during $30 \mathrm{~min}$, triphenylphosphine-gold(I)chloride ( $154 \mathrm{mg}, 0.311 \mathrm{mmol})$ was added. The color of the reaction mixture changed to orange and an orange-red precipitate was observed. The reaction mixture was filtered-off and the isolated precipitate was dissolved in $10 \mathrm{~mL}$ of pyridine. Transparent orange crystals with a block shape and suitable for X-ray diffraction were obtained after $48 \mathrm{~h}$ by slow evaporation of the solvent, and vacuum-dried in a Schlenk vessel for three days. Yield: \{[(1-(2-bromophenyl)-3-(2-nitrophenyl)triazenide] (triphenylphosphine)gold(I)\} (0.216 g, $0.227 \mathrm{mmol}), 89 \%$ based on the employed mass of triphenylphosphine-gold(I) chloride; m.p.: $138^{\circ} \mathrm{C}$; Anal. Calc. for $\mathrm{C}_{30} \mathrm{H}_{23} \mathrm{AuBrN}_{4} \mathrm{O}_{2} \mathrm{P}$ : C, 46.23; H, 2.97; N, 7.19\%. Found: C, 45.20; H, 2.84; N, $6.83 \%$.

\section{Single-crystal X-ray diffraction}

A single-crystal sample was attached to a glass wire and was subjected to the collection of diffraction data at room temperature $\left(20-22{ }^{\circ} \mathrm{C}\right)$ with a Bruker APEX II CCD diffractometer, with an area detector and monochromatized Mo-K $\alpha$ radiation with graphite monochromator (Bruker, 2004). Data integration and absorption correction were performed with SAINT (Bruker, 2004) and SADABS (Sheldrick, 1996) softwares, respectively. Structures were solved by direct methods (Burla et al., 2005) and refined using the square of the structure factor (F2) and complete matrices, with anisotropic thermal parameters for all non-hydrogenic atoms (Sheldrick, 1997). Fractional coordinates of hydrogen atoms of the phenyl rings were obtained geometrically $\left(\mathrm{C}-\mathrm{H}=0.93 \AA\right.$ for the $\mathrm{C}_{\mathrm{SP} 2}$ atoms), refined and attached to their respective carbon atoms and isotropic thermal parameters with values $U_{\text {iso }}$ $(\mathrm{H})$ relating to $1,2 \mathrm{U}_{\mathrm{eq}} \mathrm{C}_{\mathrm{sp} 2}$. Tables with crystallographic parameters and details regarding data collection were generated with the WinGX program (Farrugia, 1999), and graphical representations of structures and/or structural details discussed were generated with the DIAMOND (Brandenburg, 2005) program.

\section{In vitro antiproliferative activity}

\section{Cell culture}

The Chronic Myeloid Leukemia K562 cell line, 
established from the sample of a 53 - year-old patient was commercially acquired at the Cell Bank of Rio de Janeiro - BCRJ, Paul Erlich Technical and Scientific Association - APABCAM. Cells were cultured in Roswell Park Memorial Institute (RPMI) 1640 medium supplemented with $10 \%$ fetal bovine serum (Gibco ${ }^{\circledR}$ SBF-), $100 \mathrm{IU} / \mathrm{ml}$ penicillin $\mathrm{G}, 100 \mathrm{mg} / \mathrm{ml}$ streptomycin for $24 \mathrm{~h}$ at $37^{\circ} \mathrm{C}$ in a humid atmosphere with $5 \%$ carbon dioxide $\left(\mathrm{CO}_{2}\right)$.

\section{Cytotoxicity assay}

The cytotoxic effect of the complex on the cell line K562 was performed using the colorimetric assay based on the reduction of diazonium salt bromide 3-(4,5-dimethylthiazol-2-yl)-2,5-diphenyltetrazolium bromide (MTT) (Mosmann, 1983). The compound was dissolved in a mixture of ultra-pure water and dimethylsulfoxide DMSO $(1: 1)$ and then diluted at different concentrations $(100,50,25,12,6,3,1.5$ and $0.75 \mu \mathrm{M})$. In the cytotoxicity assay, $3 \times 10^{6}$ cells/well were used in a 96-well plate exposed to different concentrations of the compound and incubated for $20 \mathrm{~h}$. Control culture containing cells in the absence of the compound was also performed. Imatinib mesylate (Glivec) was the antineoplastic used as reference. After 20h, each well was treated with 20 microliters (uL) of MTT and plates were re-incubated for additional $4 \mathrm{~h}$ at $37{ }^{\circ} \mathrm{C}$ and $5 \%$ $\mathrm{CO}_{2}$. After incubation, formazan crystals were dissolved by addition of DMSO and the inhibition of cell growth detected by measuring absorbance at 570 nanometers $(\mathrm{nm})$ using an Epoch ${ }^{\circledR}$ microplate reader (Fisher BT2000 Bio-Tek). Each test was performed in triplicate in three independent tests. Results were statistically analyzed by SISVAR software (Ferreira, 1988). For cell death values $(\%)$, analysis of data variance was performed and means were compared by Tukey test at $5 \%$ error probability. $\mathrm{IC}_{50}$ values corresponding to the concentration of compound able to inhibit growth of $50 \%$ of the cells were analyzed by GraphPad Prism 5.

\section{In vitro antibacterial activity}

\section{Isolates and bacterial strains}

The in vitro antibacterial activity of the $\mathrm{Au}$ (I) triazenide complex was evaluated against seven CoNS bacterial isolates, obtained from an investigation of contamination in platelet concentrates. These microorganisms have been characterized as biofilm producers by adhesion to a borosilicate tube and Congo red agar phenotypic methods (Christensen et al., 1982; Freeman, Falkiner, Keane, 1989), and by screening for ica ACD genes by polymerase chain reaction (PCR)
(Arciola et al., 2005). Isolates were two Staphylococcus epidermidis, one Staphylococcus saprophyticus, three Staphylococcus haemolyticus and one Staphylococcus warneri. Two strains of international reference standard (American Type Culture Collection - ATCC) of nonbiofilm-producing Staphylococcus epidermidis 12228 and Staphylococcus saprophyticus 15305 were also used.

Determination of the minimum inhibitory concentration (M/C)

Bacterial isolates and ATCC strains, stored in $15 \%$ glycerol at $-80{ }^{\circ} \mathrm{C}$, were pre-activated using the agar trypticase soy medium (TSA) for $24 \mathrm{~h}$ at $35 \pm 2$ ${ }^{\circ} \mathrm{C}$. Evaluation of antibacterial activity of the compound was performed using the conventional method of broth microdilution for Minimum Inhibitory Concentration (MIC) based on the Clinical and Laboratory Standards Institute guidelines (CLSI, 2012). The test compound was diluted in DMSO and ultra-pure water $(1: 1)$ at a concentration of $2560 \mu \mathrm{g} \mathrm{mL}^{-1}$ and then successive dilutions were made with concentrations from 128 to $0.25 \mu \mathrm{g} \mathrm{mL}^{-1}$. The bacterial inoculum was prepared using a $0.5 \mathrm{McF}$ arland scale, so that each well contained $5 \times 10^{5}$ $\mathrm{CFU} \mathrm{mL}{ }^{-1}$. Plates were incubated for $24 \mathrm{~h}$ at $35 \pm 2{ }^{\circ} \mathrm{C}$ and after this period, the MIC was determined visually as the lowest concentration that completely inhibited growth of microorganisms in dilution wells. Each assay was performed in triplicate.

\section{ETHICAL CONSIDERATIONS}

This study was approved by the Research Ethics Committee (CEP) of UFSM, under the certificate number of presentation for ethical consideration (CAAE) 0285.0.243.000-09.

\section{RESULTS AND DISCUSSION}

\section{Crystal structure}

Glassy crystals with orange prismatic habit were obtained from slow evaporation of the stock solution. Values of the unit cell parameters were obtained based on the refinement of reflections obtained in different quadrants of Ewald sphere, related to the angular region and refined by the least squares method at the end of the collection of intensity data. Crystallographic parameters and further details regarding the collection of data and refinement of the complex are listed in Table I.

The geometry of the Au (I) triazenide complex is linear, with a ligand triazenide $[\mathrm{Au}-\mathrm{N} 13=2.075(3) \AA]$ 
TABLE I - Data from intensity collection and refinement of the crystal/molecular structure of the $\mathrm{Au}(\mathrm{I})$ triazenide complex

\begin{tabular}{l}
\hline Crystallography Para \\
\hline Molecular Formula \\
Molecular Mass (g) \\
Color/Shape \\
Dimensions (mm) \\
Lattice System \\
Space Group \\
Unit cell parameters
\end{tabular}

Volum

Z

Density (calculated)

$F(000)$

Wavelenght/Radiation

Absorption coeficiente

$\Theta$ Range

Index Range

Structure Solution

Direct Methods

(SIR-2004)

Structure refinement

Refining methods

Reflections collected

SHELXL-97

Reflections observed

Reflexões observadas

Data/restraints/Parameters

Goodness-of-fit on $\mathrm{F}^{2}$

Final $\mathrm{R}_{\text {indices }}[\mathrm{I}>2 \sigma(\mathrm{I})]$

$\mathrm{R}$ indices (all data)

Largest Diff (Peak and Hole)

Least squares,complete matrix including $F^{2}$

\section{2}

$6939\left[R\left({ }_{\text {int }}\right)=0,0460\right]$

4912

$6939 / 0 / 352$

1,040

$R_{1}=0,0333$

$w R_{2}=0,0656$

$R_{1}=0,0587$

$w R_{2}=0,0729$

e $\left(1,12\right.$ e. $\left.\AA^{3}\right)$ for 0,$9867 ; 0,0787 ; 0,2291$ [1.01 $\AA$ of Br]. ${ }^{\mathrm{f}}(-1,20$ e. $\AA^{3}$ ) for 0,$7871 ; 0,1271 ; 0,2339$ [0.84 $\AA$ of $\left.\mathrm{Br}\right]$

and a neutral molecule triphenylphosphine $[\mathrm{Au}-\mathrm{P}=2.224$ (11) A] bound to the gold ion with an angle [N13-P-Au = $178.72(9)^{\circ}$ ] near $180^{\circ}$, confirming the linearity, as shown in Figure 2.

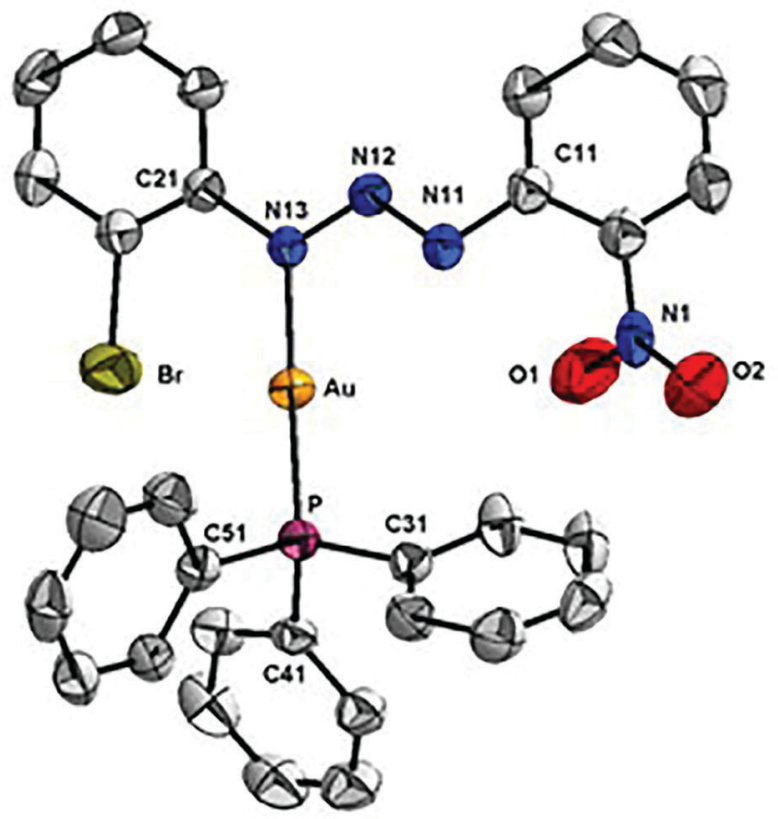

FIGURE 2 - Triazenide gold complex structural projection (I). Thermal ellipsoids with probability level of $50 \%$. Hydrogen atoms omitted for better viewing.

In the solid state, the structure of the complex is formed by non-classic aromatic hydrogen bonds type $\mathrm{C}-\mathrm{H} \cdots \mathrm{M}$ (where $\mathrm{M}$ represents the centroid point of the aromatic ring). These interactions involve a polarized hydrogen atom of a $\mathrm{C}-\mathrm{H}$ group donor of a phenyl ring of triphenylphosphyne in a unit of a molecular complex, and an acceptor ring of another phenyl of triphenylphosphyne, resulting in the formation of centrosymmetric dimers. These dimers are reproduced by the same type of interaction, forming a supramolecular arrangement 1- D.

This complex fragments involved in the determination of these interactions are C31-C36/ C56'-C51' for the formation of centrosymmetric dimers, as represented in Figure 3.

In addition to the previous determinations, it is necessary to determine the angles and distances between the two rings. These distances and angles are listed in Table II. The centrosymmetric dimers of the complex, formed by aromatic interactions, are projected in Figure 4.

These centrosymmetric dimers in the structure of the complex are reproduced by aromatic interactions $(\mathrm{C}-\mathrm{H}$ $\cdots \mathrm{Ph}$ ), resulting in supramolecular 1-D arrangements via non-classical aromatic centrosymmetric hydrogen bonds $\mathrm{C}-\mathrm{H} \cdots \mathrm{M}(\mathrm{M}=$ centroid of the ring) between the triphenylphosphine phenyls, both in the crystallographic direction [100].

The fragments considered in these interactions are C41-C46 / C51 '- C56' '[symmetry Codes (' '): 
Synthesis, characterization and biological activity of a gold(I) triazenide complex against chronic myeloid leukemia cells

TABLE II - Geometric parameters for the non-classical aromatic hydrogen bonds $(\mathrm{C}-\mathrm{H} \cdots \mathrm{Ph})$ of the complex dimers

\begin{tabular}{ccccccc}
\hline $\mathbf{D}-\mathbf{H} \cdots \mathbf{A}$ & $\mathbf{D} \cdots \mathbf{A}(\boldsymbol{\AA})$ & $\mathbf{H} \cdots \mathbf{A}(\AA)$ & $<\mathbf{D}-\mathbf{H} \cdots \mathbf{A}\left({ }^{\circ}\right)$ & $\mathbf{D}(\mathbf{M})(\AA)$ & $\mathbf{d}(\mathbf{M})(\AA)$ & $<\mathbf{P h}-\mathbf{H}-\mathbf{M}\left(^{\circ}\right)$ \\
\hline $\mathbf{C 3 2}-\mathbf{H 3 2} \cdots \mathbf{C 5 6} \mathbf{C}^{\prime}$ & $\mathrm{C} 32 \cdots \mathrm{C} 56^{\prime}$ & $\mathrm{H} 32 \cdots \mathrm{C} 56^{\prime}$ & $\mathrm{C} 32-\mathrm{H} 32 \cdots \mathrm{C} 56^{\prime}$ & $\mathrm{C} 32 \cdots \mathrm{M}$ & $\mathrm{H} 32 \cdots \mathrm{M}$ & $\mathrm{C} 32-\mathrm{H} 32 \cdots \mathrm{M}$ \\
& 3,836 & 3,076 & 140,06 & 3,946 & 3,363 & 122,61 \\
\hline
\end{tabular}

$\mathrm{M}=$ centroid point of the aromatic ring. [Symmetry codes: ('): $\mathrm{x}-1, \mathrm{y}-2, \mathrm{z})$ ].

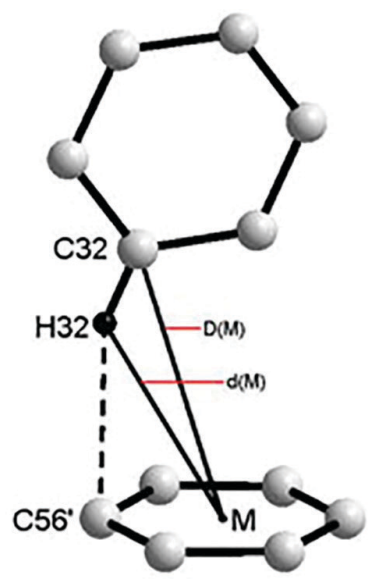

FIGURE 3 - Projection of fragments involved in the non classical aromatic hidrogen bondings $\mathrm{C}-\mathrm{H} \cdots \mathrm{Ph}$ of the dimers of the C31-C36 / C51'-C56 'complex. [Symmetry Code x-1, y-2, z]. Hydrogen atoms are omitted for better layout view. $\mathrm{M}=$ centroid point of the aromatic ring.

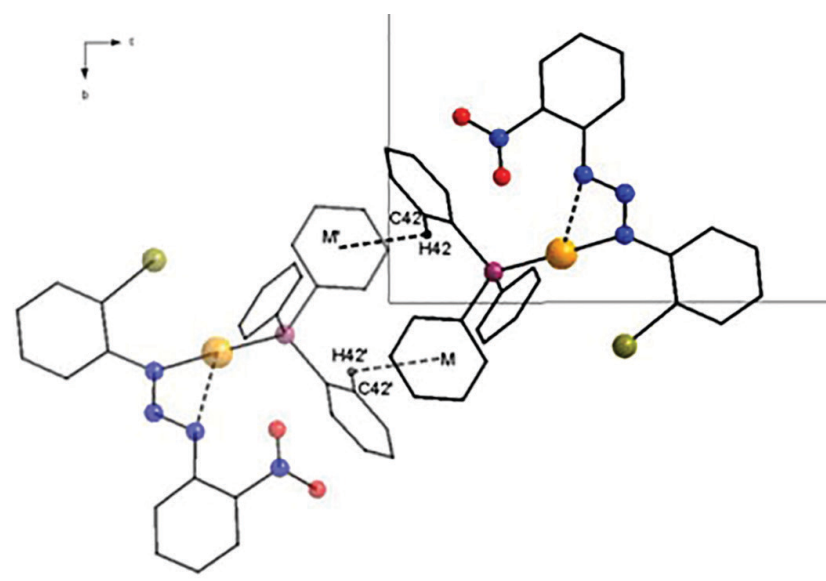

FIGURE 4 - Projection of the centrosymmetric dimers of the complex, in the crystallographic direction of the $\alpha$ axis, formed by non-classical aromatic hydrogen bonds $\mathrm{C}-\mathrm{H} \cdots \mathrm{M}$ (where $\mathrm{M}$ is the centroid point of the aromatic ring C51'-C56'). Hydrogen atoms are omitted for better viewing. Showing partial cell content. [Symmetry Code ('): $\mathrm{x}-1, \mathrm{y}-2, \mathrm{z}$ ]. [Código de simetria ('): 1-x, 2-y, -z].

$-1+\mathrm{x}, \mathrm{y}, \mathrm{z}]$. Figure 5 shows the considered fragments with all denominations, which are essential to determine interactions, and these values are described in Table III.

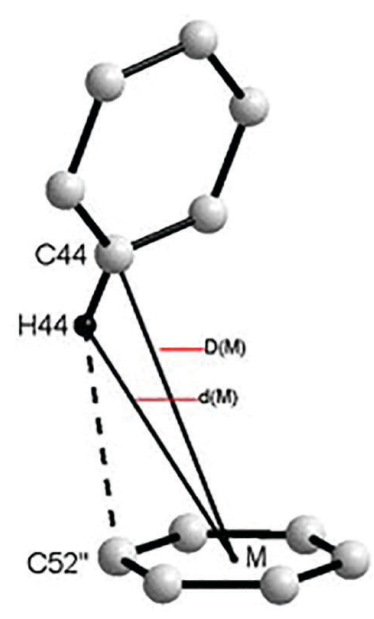

FIGURE 5 - Projection of fragments involved in non-classical aromatic hydrogen bonding $\mathrm{C}-\mathrm{H} \cdots \mathrm{Ph}$ on $\mathrm{C} 41-\mathrm{C} 46$ / C51' - C56' complex. [Symmetry Codes ("): $-1+\mathrm{x}, \mathrm{y}, \mathrm{z}$ ]. Hydrogen atoms are omitted for better layout view. $\mathrm{M}=$ centroid point of the aromatic ring.

Figure 6 depicts the projection of the supramolecular arrangement of the complex formed by centrosymmetric dimers reproduced in a $1-\mathrm{D}$ chain via non-classical aromatic centrosymmetric hydrogen bonds $(\mathrm{C}-\mathrm{H} \cdots \mathrm{Ph})$ in the crystallographic direction [100].

\section{Biological activity}

When produced by microorganisms, biofilm protects against host defense mechanisms, preventing or hindering the diffusion of antimicrobials (Høiby et al., 2010). The concentration of antibiotic required to combat infections caused by biofilm- producing microorganisms can be up to a thousand times higher compared to infections caused by their planktonic counterparts (non-biofilm producers) (Musk, Hergenrother, 2006; Høiby et al., 2010).

The tested compound showed significant antibacterial activity when compared to non-biofilm-producing strains. The results of this activity are shown in Table IV. It can be observed that among the seven biofilm-producing clinical isolates, all had MICs lower or equal to those of strains that do not produce biofilm. A study by Presterl and colleagues (2009) has shown that bacterial isolates of biofilm- 
TABLE III - Geometric parameters for the non-classical aromatic hydrogen bonds $(\mathrm{C}-\mathrm{H} \cdots \mathrm{Ph})$ of the 1-D arrangement of the complex

\begin{tabular}{|c|c|c|c|c|c|c|}
\hline D-H $\cdots A$ & $\mathbf{D} \cdots \mathbf{A}(\AA)$ & $\mathbf{H} \cdots \mathbf{A}(\AA)$ & $<\mathrm{D}-\mathrm{H} \cdot \cdots \mathbf{A}\left({ }^{\circ}\right)$ & $\mathbf{D}(\mathbf{M})(\AA)$ & d(M) $(\AA)$ & $<\mathrm{Ph}-\mathrm{H}-\mathrm{M}\left(^{\circ}\right)$ \\
\hline C44-H44‥C52” & $\mathrm{C} 44 \cdots \mathrm{C} 52 ”$ & $\mathrm{H} 44 \cdots \mathrm{C} 52 ”$ & $\mathrm{C} 44-\mathrm{H} 44 \cdots \mathrm{C} 52 ”$ & $\mathrm{C} 44 \cdots \mathrm{M}$ & $\mathrm{H} 44 \cdots \mathrm{M}$ & $\mathrm{C} 44-\mathrm{H} 44 \cdots \mathrm{M}$ \\
\hline & 3,658 & 2,821 & 150,43 & 3,911 & 3,291 & 126,03 \\
\hline
\end{tabular}

$\mathrm{M}=$ centroid point of the aromatic ring. [Symmetry codes: (') $):-1+\mathrm{x}, \mathrm{y}, \mathrm{z}$ ].

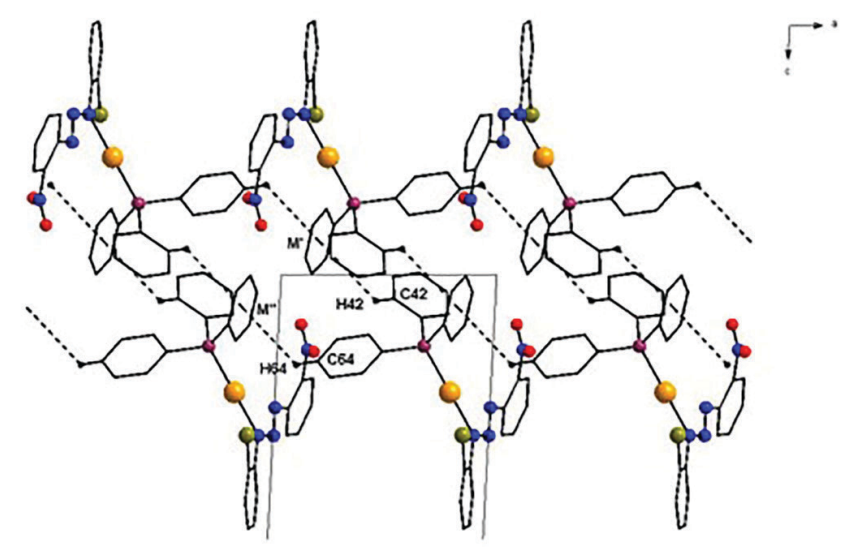

FIGURE 6 - Projection of the supramolecular arrangement of the complex in the crystallographic direction of the axis b, formed by non-classical aromatic hydrogen bondings C54-H54 $\cdots \mathrm{M}$ " (where $\mathrm{M}$ is the centroid point of the aromatic ring C51 " - C56 '). Hydrogen atoms are omitted for better visualization. Showing partial cell content. [Symmetry code ('): $-1+\mathrm{x}, \mathrm{y}, \mathrm{z}$ ].

TABLE IV - Antibacterial activity profile of (1-(2-bromophenyl)3-(2-nitrophenyl) triazenide] (triphenylphosphine) gold (I) against biofilm producing CoNS isolates

\begin{tabular}{lc}
\hline Microorganisms & $\begin{array}{c}\text { MIC } \\
(\boldsymbol{\mu g} / \mathbf{m L})\end{array}$ \\
\hline Staphylococcus epidermidis & $=32$ \\
Staphylococcus epidermidis & $=32$ \\
Staphylococcus saprophyticus & $=32$ \\
Staphylococcus haemolyticus & $=64$ \\
Staphylococcus haemolyticus & $=32$ \\
Staphylococcus haemolyticus & $=64$ \\
Staphylococcus warneri & $=64$ \\
Staphylococcus epidermidis ATCC $12228^{*}$ & $=64$ \\
Staphylococcus saprophyticus ATCC $15305^{*}$ & $=64$ \\
\hline
\end{tabular}

*Non-biofilm producing ATCC strains.

producing $S$. epidermidis have increased resistance to antibiotics. These researchers evaluated the combination of azithromycin at a concentration of $512 \mu \mathrm{g} / \mathrm{ml}$ with high concentrations of ceftriaxone, showing a significant bactericidal effect (Presterl et al., 2009). The studied Au (I) triazenide complex proved to be more active, compared to these antimicrobial agents, being capable of inhibiting all isolates of biofilm-producing $S$. epidermidis, at a concentration four times lower $(32 \mu \mathrm{g} / \mathrm{mL})$.

Several studies using TZC compounds have shown that these compounds have broad antimicrobial activity (Hörner et al. 2008; Domingues et al., 2010; Ombaka et al., 2012; Paraginski et al., 2014; Tizotti et al., 2016). Studies suggest that the antibacterial action of TZCs is due to the chelating activity of metal ions that are constituents of the bacteria cell wall, hindering their synthesis and leading to cell death (Hörner et al. 2008; Ombaka et al., 2012). According to Paraginski and colleagues, complexation of TZC compounds with metal ions such as gold (I) can provide potent antibacterial activity (Paraginski et al., 2014). However, this is, to the best of our knowledge, the first study to use such compounds complexed with metals like gold against biofilm-producing microorganisms isolated from platelet concentrates.

In a study using gold nanoparticles against multidrug-resistant bacteria, it has been observed that they act altering membrane potential and decreasing the synthesis of adenosine triphosphate (ATP), causing a general decline in bacterial metabolism (Cui et al., 2012). Barreiro et al. (2012) reported that this metal acts inhibiting bacterial proliferation by blocking cell cytokinesis (Barreiro et al., 2012).

Domingues et al. (2010), obtained MIC values $>128$ $\mathrm{mg} / \mathrm{mL}$ using TZCs not complexed with metal compounds against an $S$. epidermidis clinical isolate, as well as $S$. epidermidis ATCC 12128 strain (Domingues et al., 2010). In addition, another study using 15 TZC compounds not associated with metal showed MIC values $=64 \mathrm{mg} / \mathrm{mL}$ for hospital isolates of $S$. epidermidis and $S$. saprophyticus (Horner et al., 2008). In both studies, the compounds showed lower activity compared to $\mathrm{Au}$ (I) triazenide. Thus, we believe that part of the significant antibacterial activity demonstrated is due to the complexation of TZC with metal, which potentiates its action.

As for the anti-proliferative activity, we can see the percentage of cell death obtained by the compound, as shown in Table V. We observed that the compound 
TABLE V - Antiproliferative activity of compound \{(1-(2-bromophenyl)-3-(2-nitrophenyl) triazenide] (triphenylphosphine) gold (I)\} against K562 cells

\begin{tabular}{|c|c|c|c|c|}
\hline \multirow{2}{*}{$\begin{array}{l}\text { Concentration } \\
(\mu \mathrm{M})\end{array}$} & \multicolumn{2}{|c|}{$\begin{array}{c}\text { TZC Complex } \\
\text { Au (I) triazenide complex }\end{array}$} & \multicolumn{2}{|c|}{ Imatinib mesylate } \\
\hline & $\%$ Cell death & $\mathrm{IC}_{50}(\mu \mathrm{M})$ & $\%$ Cell death & $\mathrm{IC}_{50}(\mu \mathrm{M})$ \\
\hline 100 & $49.77 \mathrm{ab}$ & \multirow{8}{*}{4.96} & $60,35 b$ & \multirow{8}{*}{3,86} \\
\hline 50 & $60.18 \mathrm{c}$ & & $56,60 \mathrm{~b}$ & \\
\hline 25 & $58.16 \mathrm{c}$ & & $57,05 b$ & \\
\hline 12 & $57.71 \mathrm{c}$ & & $54,81 b$ & \\
\hline 6 & $52.12 \mathrm{~b}$ & & $54,36 \mathrm{~b}$ & \\
\hline 3 & $50.00 \mathrm{ab}$ & & $57,61 \mathrm{~b}$ & \\
\hline 1.5 & $48.99 \mathrm{ab}$ & & $55,82 b$ & \\
\hline 0.75 & $47.54^{\mathrm{a}}$ & & $41,83^{\mathrm{a}}$ & \\
\hline Media & 53.06 & & 54,8 & \\
\hline CV $(\%)$ & 2.66 & & 4,4 & \\
\hline
\end{tabular}

Means followed by the same letter do not differ by Tukey test at $5 \%$ error probability $(\mathrm{p}<0.05)$. Coefficient of variation $(\mathrm{CV})$.

activity was not dose-dependent, being more active in the concentration of $50 \mathrm{uM}$, which was also evidenced by Domingues et al. (2010) in trials with TZCs against AML cells (Domingues et al., 2010). In addition, concentrations of 50,25 and $12 \mu \mathrm{M}$ showed no significant difference through the statistical analysis of results, as well as the concentrations of 100, 3 and $1.5 \mu \mathrm{M}$. Imatinib Mesylate (Glivec) showed no significant difference in the established concentrations, except for the concentration of $0.75 \mu \mathrm{M}$. Regarding IC50, we found that the Au (I) triazenide complex showed cytotoxicity value lower than imatinib mesylate (Glivec), which is the standard drug used for the treatment of CML.

According to Marchesi et al. (2007), the cytotoxic action of TZCs occurs by methylation of the $\mathrm{O}_{6}$ position of a guanine base of DNA, mediated by methyldiazonium ion $(\mathrm{N}+\mathrm{CH} 3 \mathrm{~N})$, a highly reactive derivative of these compounds. For this reason, guanine loses the ability to bind to cytosine, creating an incorrect pair of bases, for the methylated guanine preferentially binds to thymine (Marchesi et al., 2007).

Primary studies have shown that TZC compounds may have their activity related to the inhibition of the tyrosine kinase enzyme (Matheson et al., 2004), which is directly related to the malignancy of CML (Gora-Tybor, Robak, 2008). Furthermore, it is known that the acquired resistance to tyrosine kinase inhibitors have been a problem for several patients with this malignancy (Yun et al., 2014; Wang et al., 2015).

In clinical practice, drugs bound to this metal have been especially studied in cultured cells systems, where it is possible to assess their cytotoxic potential (Gouvea et al., 2012; Bertrand, Casini, 2014). Gold organometallic compounds play an important role in medicinal chemistry, and these studies were determinant to trigger an enormous interest in the scientific community for new complexes of this metal, aiming their application to antitumor therapy (Bertrand, Casini, 2014), rheumatoid arthritis therapy, and viral and parasitic diseases (Berners-Price, Filipovska, 2011).

\section{CONCLUSION}

A new gold(I) triazenide complex, namely $\{[(1-(2-b r o m o p h e n y l)-3-(2-n i t r o p h e n y l) t r i a z e n i d e]$ (triphenylphosphine)gold(I) $\}$ was synthetized and fully characterized including the X-ray single crystal structure analysis demonstrating its undoubted molecular structure in the solid state.

According to the results, we suggest that the significant biological activity demonstrated by the $\mathrm{Au}$ (I) triazenide complex studied is due to the presence of gold ion which enhances the action of diazoamine group. Moreover, this research is part of an initial study, the first investigation to use $\mathrm{Au}$ (I) triazenide complex against K562 cells and biofilm-producing bacteria. As a result, other analyses are being carried out through the synthesis of new TZC compounds complexed with metals, as well as the elucidation of the possible mechanisms of action.

\section{ACKNOWLEDGMENTS}

This work received financial support from $\mathrm{CNPq}$ (Proc. 485262/2013-4). We would like to thank CNPq (Proc. 305254/2009-0) (M.H.) for the grant. 


\section{SUPPLEMENTARY MATERIAL}

CCDC 1483264 contains the supplementary crystallographic data for this paper. These data can be obtained free of charge from The Cambridge Crystallographic Data Centre via www.ccdc.cam.ac.uk/ data_request/cif.

\section{REFERENCES}

Arciola CR, Gamberini S, Campoccia D, Visai L, Speziale P, Baldassarri L, et al. A multiplex PCR method for the detection of all five individual genes of ica locus in Staphylococcus epidermidis. A survey on 400 clinical isolates from prosthesisassociated infections. J Biomed Mater Res. 2005;75(2): 408-413.

Barreiro E, Casas JS, Couce MD, Sánchez A, Seoane R, Estévez AP, et al. Synthesis and antimicrobial activities of gold(I) sulfanylcarboxylates. Gold Bull. 2012;45(1):23-34.

Berners-Price SJ, Filipovska A. Gold compounds as therapeutic agents for human diseases. Metallomics. 2011;3(9):863-873.

Bertrand B, Casini A. A golden future in medicinal inorganic chemistry: the promise of anticancer gold organometallic compounds. Dalton Trans. 2014;43(11):4209-4219.

Bonmassar L, Marchesi F, Pascale E, Franzese O, Margison GP, Bianchi A, et al. Triazene compounds in the treatment of acute myeloid leukemia: a short review and a case report. Curr Med Chem. 2013;20(9):2389-2401.

Brandenburg K. DIAMOND. 2004-2005, Version 3.1. Bonn, Germany: Crystal impact GbR; 2005.

Brown-Jaque M, Calero-Cáceres W, Muniesa M. Transfer of antibiotic resistance genes via

phage-related mobile elements. Plasmid. 2015;79:1-7.

Bruker. APEX2 (Version 1.0.22), COSMO (Version 1.48), SAINT (Version 7.06A). Madison, Wisconsin, USA: Bruker AXS Inc.; 2004.

Burla MC, Caliandro R, Camalli M, Carrozzini B, Cascarano GL, De Caro L, et al. SIR2004 - an improved tool for crystal structure determination and refinement. J Appl Cryst. 2005;38:381-388.
Chauffaille MLLF, Bandeira ACA, Silva ASG. Diversity of breakpoints of variant Philadelphia chromosomes in chronic myeloid leukemia in Brazilian patients. Rev Bras Hematol Hemoter. 2014;37(1):17-20.

Christensen GD, Simpson WA, Bisno AL, Beachey EH. Adherence of slime producing strains of Staphylococcus epidermidis to smooth surfaces. Infect Immun. 1982;37(1):318326.

Clinical Laboratory Standards Institute. CLSI. Methods for dilution antimicrobial susceptibility tests for bacteria that grow aerobically; Approved Standart. CLSI document M07-A9. 9th ed. Wayne, PA: CLSI; 2012.

Cui Y, Zhao W, Tian Y, Zhang W, Lü X, Jiang X. The molecular mechanism of action of bactericidal gold nanoparticles on Escherichia coli. Biomaterials. 2012;33(7):2327-2333.

Domingues VO, Hörner R, Reetz LGB, Kuhn F, Coser VM, Rodrigues JN, et al. In vitro evaluation of triazenes: DNA cleavage, antibacterial activity and cytotoxicity against acute myeloid leukemia cells. J Braz Chem Soc. 2010;21(12):22262237

Farrugia LJ. WinGX - an integrated system of windows programs for solution, refinement and analysis of single crystal x-ray diffraction data, vers. 1.64.04. J Appl Cryst. 1999;32:837838 .

Ferreira DF. SISVAR - sistema de análise de variância para dados balanceados. Lavras: UFLA; 1988. 19 p.

Freeman DJ, Falkiner FR, Keane CT. New method for detecting slime production by coagulase negative Staphylococci. J Clin Pathol. 1989;42(8):872-874.

Gora-Tybor J, Robak T. Targeted drugs in chronic myeloid leukemia. Curr Med Chem. 2008;15(29):3036-3051.

Gouvea LR, Garcia LS, Lachter DR, Nunes PR, Pereira FC, Silveira-Lacerda EP, et al. Atypical fluoroquinolone gold(III) chelates as potential anticancer agents: relevance of DNA and protein interactions for their mechanism of action. Eur J Med Chem. 2012;55:67-73.

Heim S, Mitelman F. Cancer cytogenetics. 3 ed. New Jersey: Wiley-Blackwell; 2009. 736 p. 
Høiby N, Bjarnsholt T, Givskov M, Molin S, Ciofu O. Antibiotic resistance of bacterial biofilms. Int J Antimicrob Ag. 2010;35(4):322-332.

Hörner M, Giglio VF, Santos AJRWA, Westphalen AB, Iglesias BA, Martins PR, et al. Triazenes and antibacterial activity. Rev Bras Ciênc Farm. 2008;44(3):441-449.

Marchesi F, Turriziani M, Tortorelli G, Avvisati G, Torino F, Vecchis L. Triazene compounds: mechanism of action and related DNA repair systems. Pharmacol Res. 2007;56(4):275287.

Matheson SL, McNamee JP, Wang T, Alaoui-Jamali MA, Tari AM, Jean-Claude BJ. The combi-targeting concept: dissection of the binary mechanism of action of the combi-triazene SMA41 in vitro and antitumor activity in vivo. J Pharmacol Exp Ther. 2004;311(3):1163-1170.

Moore DS, Robinson SD. Catenated nitrogen ligands part I. Transition metal derivatives of triazenes, tetrazenes, tetrazadienes, and pentazadienes. Adv Inorg Chem Radiochem. 1986;30:1-68.

Mosmann T. Rapid colorimetric assay for cellular growth and survival: application to proliferation and cytotoxicity assay. $\mathrm{J}$ Immunol Methods. 1983;65(1-2):55-63.

Musk DJJr, Hergenrother PJ. Chemical countermeasures for the control of bacterial biofilms: effective compounds and promising targets. Curr Med Chem. 2006;13(18):2163-2177.

Ombaka AO, Muguna A T, Gichumbi JM. Antibacterial and antifungal activities of novel hydroxytriazenes. J Environ Chem Ecotoxicol. 2012;4(7):133-136.

Paraginski GL, Berticelli CR, Zambiazi PJ, Paraginski VTK, Hörner M, Santos AJRWA, et al. In vitro antibacterial activity and toxicity toward Artemia salina Leach. of some triazene compounds. Quím Nova. 2014;37(7):1138-1444.
Presterl E, Hajdu S, Lassnigg AM, Hirschl AM, Holinka J, Graninger W. Effects of azithromycin in combination with vancomycin, daptomycin, fosfomycin, tigecycline, and ceftriaxone on staphylococcus epidermidis biofilms. Antimicrob Agents Chemother. 2009;53(8):3205-3210.

Sheldrick GM. SADABS - Program for empirical absorption correction of area detector data. Germany: University of Göttingen; 1996.

Sheldrick GM. SHELXL-97 - Program for crystal structure refinement. Germany: University of Göttingen; 1997.

Sreedhara A, Cowan JA. Catalytic hydrolysis of DNA by metal ions and complexes. J Biol Inorg Chem. 2001;6(4):337-347.

Tizotti MK, Hörner R, Freitas AGO, Kempfer CB, Bottega A, Rodrigues JN, et al. X-ray characterization and in vitro biological evaluation of 1-(4-amidophenyl)-3-(4-acetylphenyl)triazene and the gold(I) triazenide complex $\left\{\mathrm{Au}(\mathrm{I})\left[\mathrm{RPhNNNPhR} \mathrm{R}^{\prime}\right]\right.$ $[\mathrm{PPh} 3]\}\left[\mathrm{R}=(\mathrm{C} \mathrm{O}) \mathrm{NH} 2, \mathrm{R}^{\prime}=(\mathrm{C} \mathrm{O}) \mathrm{CH} 3\right]$. Inorg Chim Acta. 2016;441:78-85.

Wang W, Jianfeng Z, Li Y, Yang X, Ele Y, Tingting L, et al. Divalproex sodium enhances the anti-leukemic effects of imatinib in chronic myeloid leukemia cells partly through SIRT1. Cancer Lett. 2015;356(2 pt B):791-799.

Yun SM, Jung KE, Kim SJ, Fang Z, Son MK, Yan HH, et al. HS-438, a new inhibitor of imatinib-resistant BCR-ABL T315I mutation in chronic myeloid leucemia. Cancer Lett. 2014;348(12):50-60.

Received for publication on $10^{\text {th }}$ November 2016 Accepted for publication on $15^{\text {th }}$ April 2017 